\title{
Neoliberalism as language policy
}

\author{
I N G R I D P I L L E R \\ Department of Linguistics, C5A Macquarie University, NSW 2109, Australia \\ ingrid.piller@mq.edu.au \\ J I N H Y U N C H O \\ Department of Linguistics, C5A Macquarie University, NSW 2109, Australia \\ jean.cho@mq.edu.au
}

\section{A B S T R A C T}

This article explores how an economic ideology—neoliberalism-serves as a covert language policy mechanism pushing the global spread of English. Our analysis builds on a case study of the spread of English as a medium of instruction (MoI) in South Korean higher education. The Asian financial crisis of 1997/98 was the catalyst for a set of socioeconomic transformations that led to the imposition of "competitiveness" as a core value. Competition is heavily structured through a host of testing, assessment, and ranking mechanisms, many of which explicitly privilege English as a terrain where individual and societal worth are established. University rankings are one such mechanism structuring competition and constituting a covert form of language policy. One ranking criterion - internationalization - is particularly easy to manipulate and strongly favors English MoI. We conclude by reflecting on the social costs of elevating competitiveness to a core value enacted on the terrain of language choice. (English as a global language, globalization, higher education, medium of instruction (MoI), neoliberalism, South Korea, university rankings)*

This world that appears to them as involved in an inevitable process of globalization, is in reality, and this is the worst of it, the product of a systematic, organized, and orchestrated policy.

(Pierre Bourdieu, 2001) ${ }^{1}$

\section{N T R O D U C T I O N}

Between January and April of 2011 four students and one professor at the elite university Korea Advanced Institute of Science and Technology (KAIST) took their own lives. These suicides were widely covered in the media in South Korea (e.g. Ji, Jang, \& Kim 2011; Minjee Kim 2011) and even internationally (e.g. McDonald 
2011; Asian Scientist Newsroom 2011). The consensus that emerged in these media reports was that the pressure resulting from university reforms was to blame for these tragedies. It was particularly the fact that English had been introduced as the only medium of instruction (MoI) in this Korean institution that was singled out for blame. This article takes no stance as to whether English MoI did or did not play a role in these suicides, as all we know about them comes from media reports. Rather, we ask how a state of affairs has come about where English is widely perceived to be the cause of immense social suffering in Korean society, but where this linguistic burden is simultaneously embraced as natural and incontestable. We argue that to understand the spread of English — despite its obvious costs - one has to look outside language and link language explicitly to the socio-economic order.

Specifically, we are interested in the ways in which the global spread of neoliberal free-market doctrines naturalizes the use of English as the language of global competitiveness. Neoliberalism is an economic doctrine that has undergirded the global expansion of advanced capitalism over the past three or four decades. Its basic idea is a resuscitation of nineteenth century laissez-faire (hence, neoliberal) capitalism based on Adam Smith's competitive equilibrium model, in which the unregulated (hence, free) market is assumed to work for the benefit of all if individual competition is given free reign (cf. Stiglitz 2002:74). While laissez-faire capitalism was abandoned as a result of the labor movements of the nineteenth and early twentieth century and in the wake of the Great Depression and World War II, it was reimposed in its neoliberal guise as the so-called "Washington Consensus" first on Latin American countries with a debt crisis and later on the former communist countries of Eastern Europe by US-dominated global financial bodies such as the International Monetary Fund (IMF) and the World Bank (Duménil \& Lévy 2009). The ideological success of neoliberalism lies in a conflation of political and economic liberalism in which economic liberalism is claimed to be a precondition of political liberty, regardless of the fact that neoliberal policies have served to restrict rather than expand the choices of most people as they have resulted in unprecedented levels of global inequality and environmental destruction (Sapiro 2010).

One of the most cogent critiques of neoliberalism as an ideology that disavows all policy and regulation and thereby dissimulates its operation as a "systematic, organized, and orchestrated policy" can be found in the late writings of Pierre Bourdieu (collected posthumously in Sapiro 2010), and it is on this framework that we draw: in this article we want to show, with reference to the spread of English as medium of instruction (MoI) in higher education in South Korea, that neoliberalism with its imperative to compete is a covert form of language policy, which imposes English as a natural and neutral medium of academic excellence. By definition, neoliberalism is philosophically opposed to any form of regulation, including language policy. In this guise, neoliberal economic restructuring has managed to impose English on ever-more domains of global life while actually dissimulating its 
operation. Consequently, we consider it a task of some urgency to uncover how neoliberal free-market fundamentalism actually serves as a covert language policy mechanism.

Our article is structured as follows: we first sketch out the background by providing an overview of economic restructuring in South Korea since the Asian Financial Crisis of 1997/98 and the English frenzy it has engendered. We then move on to provide an overview of the simultaneous restructuring of higher education, which can be described as state-led corporatization. We exemplify the restructuring process particularly with reference to KAIST. In a next step, we explore how university rankings link the economic and the academic. Drawing on Bourdieu's work about the loss of academic autonomy through the intrusion of the journalistic and economic fields (Sapiro 2010), we show how mass-mediated university rankings have become drivers for academic policy. Of all of the measures that go into university rankings, internationalization is the measure that is the easiest to manipulate. Internationalization is tied to English MoI, making MoI a terrain where universities compete and a relatively cost-effective means to improve their standing in university rankings. Our argument draws on media and policy reports as data. We conclude our inquiry by reflecting on the costs of elevating competition to an educational core ideology and practice. In addition to the human cost of high levels of social suffering, the spread of English MoI must also be understood as a means of suppressing critical inquiry. We argue that resistance to neoliberal language policies dissimulating their operation must be fought through exposing precisely those costs.

THE $1997 / 98$ ASIAN FINANCIAL CRISIS AND

THE ECONOMIC RESTRUCTURING OF SOUTH K O R E A ${ }^{2}$

The KAIST suicides made headlines shortly after suicides in Asia's export-processing factories had become a major focus of the antiglobalization movement, and particularly China's labor movement (Kolo 2011). Activists make a connection between skyrocketing suicide rates in societies that have undergone neoliberal economic restructuring and the ever-deepening divides between rich and poor, the economic insecurity and the stress-inducing hypercompetition that such restructuring engenders (Klein 2007). As far as South Korea is concerned, the country's suicide rate has more than doubled since the Asian financial crisis in 1997/98. In 1995 it was 11.8 per 100,000 people (CIA world factbook, 1997; cited in Klein 2007:502) and by 2009 it had risen to 28.4 per 100,000, which translates into forty-two suicides per day (I. Song 2011). Today, South Korea has one of the world's highest suicide rates, along with other countries that have been the subject of radical economic restructuring, particularly in the former Soviet Union (World Health Organization 2011; Stuckler, King, \& Mckee 2009). Within South Korea, the prevalence of suicide has entered public consciousness to such 
a degree that the country has been dubbed jasal gonghwaguk ${ }^{3}$ 'suicide republic' (J. Choi 2010; I. Song 2011).

The actual incidence of suicides only represents the tip of the iceberg of social suffering in South Korea. In surveys as many as eight out of ten elementary and secondary school students claim they have considered committing suicide at least once in the previous year (Teen Suicide 2010). Educational researchers state that due to educational pressures contemporary Korean children are "in a constant state of extreme exhaustion, sleep-deprivation and depression" (AFP 2011).

A high degree of social suffering as expressed in a prevalence of mental health problems and culminating in a high suicide rate can thus be observed in contemporary South Korea. This increase in social suffering correlates with the Asian financial crisis in 1997/98 and the neoliberal restructuring that followed it. Social suffering is the result of a heightened state of competition where individual and collective livelihoods, security, development and well-being are continuously at stake. While the rewards and penalties in this hypercompetition where everyone competes against everyone else are real enough, most of the competition is actually symbolic and English has become one of the key terrains where South Koreans compete. The illusion of English proficiency as a "real" and "fair" marker of distinction undergirds the ideology and practice of competitiveness.

South Korea's economic development pre-1998 was achieved against the free market while the crisis and its continued effects were the result of the free market (Klein 2007). For most of the second half of the twentieth century, South Korea had experienced sustained and relatively equitable growth through a mixed, managed economy that relied on sequentially upgrading its export-oriented manufacturing to more knowledge-intensive and thus higher-value products. South Korea also used import substitution and tariffs and other trade barriers to protect its economy (Reinert 2008). However, in the 1990s, South Korea, like other Asian economies, came under increasing pressure from the newly created Word Trade Organization (WTO) to dismantle its trade barriers. South Korea agreed to what seemed like a fair compromise: it would continue to protect the chaebeols, its big state-favored national conglomerates, from foreign ownership and privatization but would lift the barriers to its financial sector and deregulate its currency (Klein 2007:267).

The immediate consequence of financial deregulation was a surge in foreign investment and currency trading. In 1996, international investors poured $\$ 100$ billion into South Korea (Klein 2007:264). However, only a year later, on the basis of rumors that Thailand did not have enough dollars to back its currency, these same investors withdrew their money in panic selling from all "Asian Tigers," including South Korea.

Asian governments were forced to drain their reserve banks in an effort to prop up their currencies, turning the original fear into a reality: now these countries really were going broke. The market responded with more panic. In one year, $\$ 600$ billion had disappeared from the stock market of Asia. (Klein 2007:265) 
Furthermore, the IMF, the global body tasked with preventing such crashes, did not respond immediately and when it responded it did not simply provide an emergency stabilization loan that a purely financial crisis demanded; nor were capital controls, the removal of which had made the crisis possible in the first place, put back into place. Instead, the IMF forced South Korea to adopt the Washington Consensus measures of deregulation, removal of caps on foreign ownership, privatization, and spending cuts in return for loans. From a national economic perspective, these measures were entirely superfluous and ill-targeted, as the IMF itself admitted in a 2000 report.

... with the benefit of hindsight, the IMF's policy advice to these countries during the emergency was not flawless, ... particularly as these countries had entered the crisis with strong fiscal positions and low public debt. While fiscal policy was not a major cause of the recessions, ... . (Recovery from the Asian crisis and the role of the IMF 2000)

A New York Times report compared the IMF-imposed measures to those of "a heart surgeon who, in the middle of an operation, decides to do some work on the lungs and kidneys, too" (quoted in Klein 2007:269).

What the IMF-imposed measures meant for South Korea was the break up and privatization of the chabeols, their sell-off to foreign investors, mass layoffs, the cowing of South Korea's militant trade unions, the privatization of public services, and the minimization of public spending. The day of the signing of the IMF agreement, November 21, 1997, was dubbed guk-chil-il 'National Humiliation Day' on par with that other 'National Humiliation Day,' August 2, 1910, when Korea was colonized by Japan. The reference to colonization is apt as the IMF not only imposed draconian economic measures but also undermined the democratic process: the IMF negotiations coincided with national elections and two of the four candidates ran on an anti-IMF platform. The IMF refused to release any emergency funds until all four candidates signed an agreement that, in the event of their election, they would do nothing to roll back the IMF-imposed measures.

For many South Koreans, IMF-imposed economic restructuring was thus an unequivocal disaster. The unemployment rate tripled and the number of those who selfidentified as middle class fell by more than a third from $63.7 \%$ in 1996 to $38.4 \%$ in 1999 (Klein 2007:272). Economic inequality sky-rocketed: the income gap between the richest and poorest ten percent of South Koreans, which had been at Canadian levels before the crisis, became larger than in any other Organization for Economic Cooperation and Development (OECD) country, that is, South Korea is now a more economically polarized society than even the US (Lim \& Jang 2006). And, as we stated at the beginning, people started to take their own lives in record numbers.

While the Asian financial crisis has been largely forgotten globally as it has been eclipsed by a string of ever-larger financial crises in the disaster capitalism of the first decade of the twenty-first century, for the people of South Korea the crisis is not over yet as can be seen from the fact that neither the unemployment rate nor the wealth-poverty gap nor the suicide rate have returned to precrisis levels. As 
Klein (2007:277) sums up: "When 24 million people [in all the Asian crisis states combined] lose their jobs in a span of two years, a new desperation takes root that no culture can easily absorb."

A key cultural change that took root in South Korean culture was the elevation of competitiveness and competition to a core value of both individuals and the state. Competition for jobs, education, housing, and other indicators of human well-being became an individual responsibility. Competition was both an outcome of economic restructuring (e.g. loss of job security, high unemployment) and an ideology that made economic restructuring possible. Despite its devastating consequences there was relatively limited opposition to IMF-imposed economic restructuringa fact that is all the more surprising when one considers that a broad coalition of trade unions, labor activists, and middle-class progressives had overthrown South Korea's long-standing military dictatorship less than a decade earlier. Klein (2007), on whose account we have mainly drawn in this section, attributes this lack of resistance to a state of collective shock - at going almost overnight from a model economy to one with a debt crisis. She argues that this state of collective shock was exploited by the IMF, multinational corporations and national conservative politicians, and media. By the time Koreans had found their bearings again, the rules of the game had changed forever.

Jesook Song (2009a, 2009b) extends this account by arguing that neoliberal restructuring did not raise more opposition because it was clad in a cultural guise, and cut-throat competition was mistaken for individual liberty and responsibility. In this account, the progressive and radical socialist movements that had been so successful in overthrowing the military dictatorship were still steamed in their fight against the authoritarian state and were thus incapable of distinguishing the discourse of the free market, that is, economic neoliberalism, from the discourse of individual freedom, that is, civil liberalism. In this account the critical idiom of the time was simply inadequate to deal with a conservative material restitution that masqueraded as the promotion of individual responsibility. The discourse of competitiveness served to disguise one as the other (see also Lim \& Jang 2006).

Indeed, Bourdieu identifies the destruction of cultures of collective action and solidarity through economic insecurity as the universal consequences of neoliberal economic restructuring. These give way to cultures of individualism with their highly competitive subjectivities (Sapiro 2010). In South Korea, English became a key expression of this new culture of competition and competitiveness and a key terrain where competition is played out, as we discuss in the next section.

YEONGEO YEOLPUNG: ENGLISH FEVER IN

THE STRUCTURES OF COMPETITION

A number of authors have recently observed the centrality of language to the neoliberal order (see Heller (2010) and Heller \& Duchêne (2012) for overviews) and the emergence of unprecedented levels of English language learning in the 
context of South Korea's economic restructuring is by now well-documented, particularly through the work of Park (2009, 2010, 2011). The levels of English language learning are such that many commentators speak of yeongeo yeolpung 'English fever' or 'English frenzy.' English fever can be found at all educational levels and takes many forms: parents enroll their children in preschools where only English is used and there is a huge shadow education market in English catering to all kinds of levels, specialized registers, and test preparations (Park \& Abelmann 2004); there are holiday camps and theme parks devoted to the practice of English (Gyeonggi English Village 2006); jogi yuhak 'short-term study abroad' is booming as is long-term study abroad (Juyoung Song 2010); and English is increasingly becoming the favored MoI in higher education (see below). As of 2009, the private market for English language learning in South Korea was said to be worth KRW1.5 trillion and the expense of English teaching accounted for forty percent of the public education budget (Yoo, Kim, \& Kim 2011). English language learning is thus better understood in economic terms as a form of consumption than in educational terms (Piller, Takahashi, \& Watanabe 2010).

English in South Korea is firmly embedded in the structures of competition. By speaking of "structures of competition" we mean that competing on the terrain of English is not a matter of individual choice but a collective imperative. While the imperative to compete is continuously exhorted as an individual responsibility, it is not the case that individuals can choose on which terrain they wish to compete. Park \& Bae (2009), for instance, found that many of the jogi yuhak parents they interviewed in Singapore wished for their children to learn Mandarin in addition to English and were rational enough to recognize that proficiency in Mandarin might be just as useful if not more useful than English for their children in their post-educational careers. However, because of the way English was heavily favored as a gatekeeping mechanism at various educational and employment transitions, they had no choice but to concentrate on English learning over Mandarin learning. These structures of competition in learning for school rather than life thus ensure a continuous privileging of English (along with a few other tested subjects): for young children, English is privileged because of its centrality on the selective high-school entrance exam. For all elementary and secondary school students and their schools, English is privileged because of its centrality on the ilje gosa, the national scholastic aptitude test, which was first introduced in 2008. For university applicants and job seekers, English is privileged because it is tested at each of these junctures. And so on and so forth.

There is no doubt that proficiency in English can confer advantages on South Koreans and that its benefits are real (Park 2011). However, the benefits of English language proficiency in South Korea are not the result of the free global market in language choice as which it has been naturalized. On the contrary, assessment mechanisms such as those we have listed above constrain the "choice" of English so heavily that it can hardly be described as choice at all. The outcomes of each test further entrench the inequalities between those for whom proficiency 
in English opens doors and those for whom lack of proficiency in English closes doors. The pressure to perform in English, that is, on tests of English, is thus immense.

This structural interpretation is borne out by anecdotal observations of the daily pressure to learn English. A blogger, for instance, reports that the pressure for a school to do well on the ilje gosa is such that principals curb break times in favor of study practice: "When seeing children playing on the playground, the principal has sometimes pressed them to memorize more English vocabulary or things of that nature" (Barbara 2010).

Mundane practices such as these, which undergird the structures of competition, are supported by widely circulating discourses that serve to naturalize competition, including competition on the terrain of English. An example of such a set of discourses is provided by Park (2010) in his analysis of mass-mediated stories of successful language learners. Despite the fact that the featured learners are all of privileged and elite backgrounds, these newspaper stories construct highly successful learners of English as morally superior individuals whose English proficiency is nothing but a result of their personal determination and superior sense of responsibility. Ethnographic evidence also indicates that proficient speakers of English indeed construe their proficiency as an expression of their moral worth and the strength of their determination (Abelmann, Park, \& Kim 2009; Jesook Song 2009a).

The new model student is an autonomous student-consumer who is responsible for managing his or her own lifelong creative capital development. ... contemporary college students are able to narrate their human capital development while obscuring the structural workings of college rank and family capital. The hubris of this new generation works against a more broadly social imagination because it acclaims individuals who do not conform to collectivist demands. (Abelmann et al. 2009:232)

While the rewards for high performance in the tests that form the structures of educational competition are widely recognized as substantial, the penalties for low performance or refusal to compete are even harsher but commonly overlooked by those focused on "the benefits of English." Shin \& Lee (2010), for instance, report that, as low performers are penalized at each juncture, the cumulative burden of low performance reaches such levels by middle school that it becomes virtually impossible to catch up from that age onwards. Consequently, parental investment in underperforming children as expressed through participation in private tutoring begins to diminish by middle school.

The system's investment into the structures of competition is even more apparent when it comes to the penalties for those who refuse to compete. For instance, when the ilje gosa was first introduced in 2008 against widespread protests by parents and educators, some elementary school teachers refused to implement it by scheduling fieldtrips or similar activities on the nationally mandated test date. They were all 
fired for disobedience and dereliction of duty. The severity of the punishment for noncompliance with mandated competition ${ }^{4}$ presents itself as particularly stark when it is set against the punishment for teachers who were found guilty of sexual harassment or for taking bribes. The punishment for such offences is usually only nominal and offenders are allowed to continue to work as teachers (H. Kim 2008).

In sum, under the guise of enhancing individual and national competitiveness as demanded by economic restructuring, a progression of high-stakes tests has been implemented in Korean education. These structures of competition allocate a central place to English - as an index of global competitiveness — as a mechanism to distinguish those who are allowed to progress to better opportunities from those who are forced to bear the burden of underperformance by being relegated to a progressively shrinking sphere of opportunity. Restructuring of higher education has followed a similar logic as we discuss in the next section.

KA IST: COMPETING FOR GLOBAL ACADEMIC E X C E L L E N C E

Academic restructuring in South Korea is part of a global push for the marketization and corporatization of universities that is often called "academic capitalism" (Slaughter \& Rhoades 2004). Academic capitalism and its attendant managerial culture celebrate global competitiveness as the highest form of academic excellence. Consequently, the creation of "world-class research universities" has topped the ambitions of education policymakers across East Asia and beyond for some time now (James \& Mok 2005). Global academic excellence is most often described as a form of "internationalization," but there is very little that is truly "international" in this model, which is simply the transfer of the US model of academic capitalism to another national context (Kauppi \& Erkkilä 2011). This model naturalizes English as the neutral medium of academic excellence. However, outside the US (and other Anglophone countries) English MoI is better seen as a self-colonizing imposition, as illustrated by P. Choi (2010) in her analysis of the introduction of English MoI at the Chinese University of Hong Kong.

We now exemplify the intersection between academic restructuring and the expansion of English MoI with one specific story of academic restructuring, namely that of KAIST, the institution where the suicides we referred to in the introduction occurred. KAIST was established in 1971 during the military dictatorship of Chung-Hee Park. It was the founding mission of KAIST to recruit the nation's brightest irrespective of their socioeconomic background to provide them with a free education so that they would serve the development of the nation as scientists and engineers (Choe 2008). KAIST thus has always had a special place in South Korean society and was intended as a cornerstone in the transformation of South Korea from an agrarian society into a modern industrialized nation. ${ }^{5}$ When it came to academic restructuring for global academic excellence, there was thus no 
question that KAIST would be one of the institutions singled out for transformation into a "world-class" university. As part of those efforts, the Ministry of Science and Education in 2004 hired Robert Laughlin as president. Laughlin is a Nobel-laureate physicist from Stanford University, who became the first foreigner ever to head a Korean university. While Laughlin clearly brought a "big name" to KAIST, he had little administrative experience to recommend him. He had no known connection to or interest in Korea, either, and, to the best of our knowledge, the only motivation he ever publicly shared for accepting the position was that the salary was "too good to refuse" (Wohn 2006:33).

Laughlin was hired to radically transform KAIST, and that is what he set out to do, stating:

The current model ... is to contract with the government to supply highly intelligent, well-trained workers to industry at low cost. The new model is to contract with parents and students to create an excellent, general-purpose educational environment weighted toward science and engineering. (Zamiska 2007)

It is difficult to find a more succinct summary of academic restructuring as an agenda to transform higher education from the service of the common good to a capitalist enterprise. Indeed, Laughlin saw himself as a free-market warrior and repeatedly spoke of his efforts as a "blitzkrieg" (Stone 2006). Predictably, Laughlin made many enemies, proved immensely unpopular, and his contract was not renewed after only three years in the position. While the issue was academic restructuring, the critical idiom failed once again by choosing to attack Laughlin personally on cultural grounds, as culturally insensitive to Korean ways. By uniting against the person of Laughlin rather than against academic restructuring, critical academics won the battle but lost the war. Taking a socio-economic agenda disguised as a cultural one at face value is a frequent fallacy (Piller 2011) and characteristic of the success of neoliberalism, as we pointed out in the introduction. In this case it opened the doors for academic restructuring to be implemented against diminished criticism by an ethnic Korean.

Laughlin's successor was Nam Pyo Suh, a Korean-American, professor emeritus at MIT, with a distinguished career in mechanical engineering. In addition to his Korean identity, Suh also brought substantial administrative experience in academic restructuring to the position, including as Head of the Department of Mechanical Engineering at MIT between 1991 and 2001 and as Assistant Director for Engineering of the National Science Foundation (NSF) between 1984 and 1988 as President Reagan's Appointee. ${ }^{6}$

Four aspects of the restructuring of KAIST in particular received widespread media attention and were credited to Suh's leadership. First, the founding mission of training the nation's brightest irrespective of their socioeconomic background was abandoned and substituted with a penalty system where fees are tied to grades. This penalty system was partly repealed after the wave of suicides in 2011 reported above. 
Second, the admission system was changed from the traditional standardized entrance exam as the single selection criterion to include other measures of student potential. Most commonly, candidates are now invited for personal interviews, asked to give presentations, and to engage in discussions with the purported aim to identify "future Einsteins and future Bill Gateses" (Normile 2007). As Bourdieu \& Passeron (1990:162) point out, it is these kinds of occasions "for passing total judgement" where class bias is strongest because they call upon "the unconscious criteria of social perception on total persons, whose moral and intellectual qualities are grasped through the infinitesimals of style or manners, accent or elocution, posture or mimicry, even clothing and cosmetics."

Thirdly, professors" "iron rice bowl" was broken through stricter tenure reviews, which included the need for endorsements from international experts. Where formerly tenure had been almost automatic after a certain length of service, under the new rules, eleven out of thirty-three professors up for tenure in 2007, when the new rules were first applied, failed to gain tenure (Normile 2007).

Finally, a 100\%-English-MoI policy was instituted on the grounds that KAIST needed to accept non-Korean students in order for the university to "internationalize" (see next section). The single-mindedness with which the 100\%-English-MoI policy has been implemented is best exemplified by the fact that under the policy even foreign languages such as Chinese or Japanese now have to be taught through the medium of English just to conform to KAIST's language policy. When the unreasonableness of teaching one foreign language through the medium of another was pointed out by a group of students to KAIST administration, the administration issued a statement asserting that "top global universities such as the Massachusetts Institute of Technology are teaching foreign languages in English only, and so should we" (Yongjadeul 2008). Justifying foreign language learning through the medium of a foreign language by comparison with an institution where foreign languages are taught through the medium of the first language and which, incidentally, is not exactly known for the quality of its foreign language instruction, can only be understood as ideological and makes sense only when the name of the game is not the mindful and rational pursuit of knowledge and the common good but the ticking of boxes designed to "measure" academic excellence.

Suh has been personally credited with restructuring KAIST and, particularly in the early days of his tenure, was widely praised both in national and international mass media. Headlines collected on the KAIST website ${ }^{7}$ included the following: "KAIST President puts reform drive in high gear" (Korea Herald); "S. Korea science prepares to take on the world" (International Herald Tribune); "MIT engineer shakes Korean academia to its core" (Science Magazine); or "Science institute's new president sets a blistering pace for reform" (Chronicle of Higher Education).

While the mass media were full of praise, a darker account of restructuring started to emerge on blogs and in independent media. Much of the criticism centred on English MoI and the suppression of free speech on campus. For instance, it emerged that Suh attempted to control the student-run newspaper KAIST Times by 
nominating himself as the publisher (Anonymous 2008). KAIST was also accused of engaging in an editing war on the Korean Wikipedia entry for KAIST with a KAIST employee repeatedly removing statements critical of Suh or the restructuring (Jeon 2011). Most seriously, it was revealed in 2011 that all new students are now required to sign a gag clause, which prohibits them from criticizing the institution or engaging in any form of protest and makes parents liable for any student protest their children might engage in (J. Lee 2011).

By mid-2011 Suh, too, was under heavy criticism and barely holding on to his job. However, by then, the restructure of KAIST was largely a fait accompli. Finally, too, critical voices started to emerge that did not focus on Suh's person but on academic restructuring. Professor Joongu Lee from Seoul National University (SNU), for instance, wrote on his blog: " "The real culprit is not Suh but those who blindly praised his reforms to give a boost to him. It is an issue that is not just limited to KAIST, but a problem that is gripping almost all institutions in the nation." Lee went on to blame mass-mediated university rankings for much of the social suffering apparent in universities across the country. In particular, he blamed the relentless pursuit of English MoI on university rankings, arguing that "increasing the number of courses taught in English is the easiest way of earning points to secure better rankings." Progressive newspapers such as Pressian soon joined Lee in condemning university rankings for the cutthroat competition engulfing universities (Chae 2011). It is therefore to university rankings that we now turn. Specifically, we show that university rankings did not only serve to further heat up the discourses of competitiveness and the practices of competition but also to promote English MoI.

\section{EN G L IS H IN U N IVERS IT Y R A N K I N G S}

University entrance in South Korea, too, follows the inevitable logic of the structures of competition with students competing for entry into "good" universities:

A university's reputation, rather than a specific department or major, tends to be the most important factor for students and parents because hiring companies generally pay more attention to the job applicant's university than to any undergraduate major. Thus, the universities are ranked in a hierarchical order that corresponds to the entrance test scores of their students. From the individual's perspective, getting a high score on the national scholastic test is the best way to guarantee entrance to a good university, to a good job, and hence to a successful career. (Shin \& Lee 2010:110ff.)

In addition to career prospects, even marriage prospects are closely tied to the rank of one's university (Korean universities: A brief introduction 2011). So, identifying and getting into the "right" university is a very important matter indeed. While the prestige of the very best universities nationally is firmly entrenched, identifying the "right" university has become more complex at the lower rungs and parents and 
students are increasingly forced to rely on university rankings for information about the standing of a university. Competition has thus created a demand for university rankings, which, in turn, fuel further competition as the most prestigious universities aim to have their high prestige empirically verified and as lower-ranked institutions strive to improve their standing.

National university rankings are published annually by two newspapers, Joongang Ilbo (since 1994) and Chosun Ilbo (since 2009). Both Joongang and Chosun are part of a group of the three major Korean newspapers (the third one being Donga Ilbo), which are collectively referred to pejoratively as Cho-Joong-Dong. ChoJoong-Dong form the basis of bosu eonlon, the conservative media. Cho-JoongDong have been part of South Korea's political and economic elite for most of its recent history and collectively espouse antisocialist, pro-US, pro-chaebeol, and, more recently, neoliberal free-market ideologies (Park 2010; Sa 2009). ChoJoong-Dong, which together have a seventy-five-percent market share, have been active agents in the promotion of English in South Korea, including stunts such as a Chosun Ilbo campaign to make English an official language, or another campaign entitled yeongeoga gyeongjaenglyeokida 'English is competitiveness,' which predicted a dire future unless the country became more "English-friendly" (see Park 2009, 2010 for details). It is against this background that mass-mediated university rankings must be understood as yet another pillar in the discourse of global competitiveness and one that is specifically played out on the terrain of English.

Both the Joongang and Chosun university rankings were introduced with the stated aim to promote international competitiveness among national universities and thus improve the quality of Korean higher education. The Joongang university rankings are modelled on the U.S. News and World Report college rankings while the Chosun rankings are modelled on the Quacquarelli Symonds (QS) rankings, with which it has partnered for the purpose. Both rankings use the same four criteria to rank universities as follows but have them weighted differently as shown in Table 1.

Except for "learning environment," each of these criteria covertly serves to promote English in slightly different ways, as we explain below.

TABLE 1. Ranking criteria of Joongang and Chosun (Ahn, Lee, Lee, Choi, \& Oh 2009; University Ranking Team 2010).

\begin{tabular}{llc}
\hline \hline & \multicolumn{1}{c}{ Joongang } & Chosun \\
\hline Research and publication & 115 points $(\approx 32.9 \%)$ & $60 \%$ \\
Learning environment & 95 points $(\approx 27.1 \%)$ & $20 \%$ \\
Social reputation of graduates and their career progress & 70 points $(\approx 20 \%)$ & $10 \%$ \\
Internationalization & 70 points $(\approx 20 \%)$ & $10 \%$ \\
\hline \hline
\end{tabular}


"Research and publication" is the most highly ranked criterion in each ranking but is measured differently by each newspaper. Chosun simply counts the number of articles per academic indexed in SciVerse Scopus over the previous five years. The Joongang measurement is a bit more complex and assigns fiftyfive (out of 115) points to "international" publications and citations in journals indexed in the Arts and Humanities Citation Index (AHCI), the Science Citation Index (SCI), and the Social Sciences Citation Index (SSCI). Fifteen points (on the research criterion) are allotted for "national" publications published in domestic journals, and the remaining forty-five points go to grant income.

Although ostensibly a language-neutral criterion, the research measurement in both cases privileges English over Korean as Kang (2009) explains with a case study of "international" publications by Korean academics in the field of communications, a discipline indexed in SSCI. In 2007, there were 1,865 journals indexed in the SSCI. 1,585 (79.62\%) of these originated in the US and UK. SSCI-indexed "international" journals are thus clearly hugely skewed towards those originating in Anglophone countries. Among Asian countries, seven SSCI-indexed journals $(0.38 \%)$ originate in Japan, five $(0.27 \%)$ in China, four $(0.21 \%)$ in India, three $(0.16 \%)$ in South Korea, and one each (0.05\%) in Singapore and Taiwan. Even those SSCIindexed journals published outside the Anglophone countries are overwhelmingly English-language publications (as are, incidentally, a fair number of domestic journals). So, adopting publication in SSCI-indexed journals as a measurement of research quality obviously translates into adopting publication in English as a quality measure. The same is true for journals indexed in SciVerse Scopus, AHCI, and SCI.

The inclusion of "social reputation of graduates and their career progress" as criterion is justified, in circular logic, with the argument that "career progress and social reputations of graduates represent the quality of education of a particular university" (Ahn et al. 2009). Joongang measures this criterion through a survey of domestic companies with seven questions each of which is weighted ten out of seventy. The survey asks purely attitudinal questions (e.g. Which university graduates would you like to hire? Which universities do you see developing in the future? Which universities would you like to donate to?). These serve to simply elicit and perpetuate existing stereotypes and reinforce discourses already in circulation. While there is no clear intersection with English in the Joongang measurement, there is in the Chosun measurement, which does not survey domestic companies but multinationals with the intent to measure the global reputation of local graduates (Oh 2009). To do so Chosun sends out questionnaires to more than 700 human resources managers at multinational corporations outside Korea asking them to select up to thirty Korean universities whose graduates excel in their experience. The survey is thus obviously skewed towards responses from environments in which English is the norm and excludes Koreans working in domestic environments no matter how well-trained and productive they may be.

The measurement of internationalization, which accounts for around twenty percent of the Joongang total and ten percent of the Chosun total, is almost identical 
in both cases. The degree to which a university is judged to be internationalized is rated on the basis of four indices (Jung 2011):

- The proportion of foreigners among a university's teaching staff

- The number of international students

- The number of exchange students

- The proportion of English-medium lectures

Improving a university's position in the rankings on research, learning environment and reputation requires long-term strategies. By contrast, the internationalization indices can be manipulated with almost instant effects on rankings. Additionally, the visibility effects of international student populations may actually also influence reputation quite quickly (Jung 2011). Indeed, as a result of these internationalization efforts the number of overseas students in South Korea increased from only 6,000 in 2000 to around 80,000 in 2010 (Morgan 2010). The preferential treatment with which international students and teachers are courted has given rise to friction between domestic and international students. In 2007, KAIST offered fifty-one full scholarships to international undergraduate students (7.3\% of the total undergraduate intake) while raising fees for domestic students (Choe 2008). The fact that domestic students face heavy competition for scarce dormitory rooms while new campus housing is especially built for foreign recruits is another example of how the internationalization of the student body is a response to competition but also serves to escalate competition.

The vast majority of the international students recruited by Korean universities come from China and other Asian countries (Morgan 2010). Even so, the expansion of English MoI is justified with the "need" to recruit international students. In another feat of circular logic, English MoI is thus seen as evidence of existing internationalization as well as an expression of the intention to internationalize. KAIST was the first Korean university to implement its 100\%-English-MoI policy and all lectures at KAIST have been conducted in English since 2010. In the same year, ninety-three percent of all lectures at Pohang University of Science and Technology (POSTECH), another highly ranked institution, were conducted in English and English lecture rates at the top ten universities averaged thirty percent (Manjung Kim 2011). As these figures demonstrate, increasing the percentage of English MoI clearly pays off in the rankings.

Cho-Joong-Dong have been full of praise for KAIST's 100\%-English-MoI policy and frequently hail it as the brave new world of Korea's linguistic future (Ko 2010). However, cracks in the façade of the wonderful image of English MoI have also started to appear. Students have expressed frustration with English lectures because they find them incomprehensible and delivered ineffectively (Cho 2012). Some have questioned the effect of English MoI on academic quality from another perspective as the ability to lecture in English has become a key hiring criterion for university teachers irrespective of their field of study or 
disciplinary expertise (Jang 2009). Financial incentives have been put in place to reward individual professors as well as departments who lecture in English while penalizing those who do not (Jung 2011) - exposing the myth of English MoI as the result of free choice as a lie yet again.

In sum, competition to do well on university rankings has forced Korean universities to adopt English MoI. Universities are driven to compete through university rankings because they have been restructured into market entities. Having to compete through university rankings on the basis of criteria imposed by mass media has resulted in further loss of autonomy and the subjugation of the academic field to the journalistic field (Sapiro 2010). However, newspapers also use university rankings to compete and as a source of profits, meaning that both, mass media and academia, have become subjected to the tyranny and censorship of money.

Before we conclude, we thus need to elucidate one final relationship, namely the one between university rankings and the competition for profit in the mass media. This relationship is best exemplified with reference to the Chosun rankings as these were only introduced in 2009. In 2009, Chosun, like all newspapers, had been losing ground because of the ongoing economic crisis and the continued expansion of digital media. Partly reinventing itself as an outlet for university rankings gave Chosun a new lease on life. When the first Chosun rankings were published in May 2009 the number of university ads in the paper had been steadily increasing for months with advertisements placed by the top twenty universities accounting for almost half of the total (E. Lee 2009). Lee (2009) concludes that "the media are taking universities hostage for selling advertisements, while urging universities to be cooperative to be granted better rankings." Furthermore, after the initial publication of the university rankings, they kept being recycled, for instance, in a June so-called "special report," which displayed a list of the top universities alongside the advertisements of those same universities (Han, Shin, Jung, Min, Kim, \& Lee 2009).

Of course, the South Korean case is not an exception in this and the high impact of university rankings on mass media revenue has been observed in other contexts as well (Ehrenberg 2003). Given the high profit potential of university rankings, it is not surprising that in 2010 yet another newspaper, Kyunghyang Shinmun, announced its intention to introduce its own university rankings enterprise (Jang 2010).

English MoI has been spreading internationally at all educational levels. Most people and, indeed, most analysts see this spread as some sort of inevitable side effect of globalization. By contrast, it has been our aim in this article to show that English MoI is imposed by an interlocking set of socioeconomic agendas dissimulating their operation. The spread of English is not a result of the free linguistic market but of a "systematic, organized, and orchestrated policy." In our account, 
economic insecurity has been instituted in South Korea since the Asian Financial Crisis of 1997/98 and economic insecurity forms the basis of hypercompetition partly fought on the terrain of English. At the same time that the state has reduced funding for education (as for other public services), the state has instituted structures of competition that serve to create the illusion of a meritocracy where a good education, good jobs, good careers, and even good marriages are promised to the winners of this universalized competition. English has been institutionalized as one of the terrains where individuals and institutions must compete to be deemed meritorious. While the imposition of English as a terrain of competition is being legitimized because of its place in global communication and academic excellence, the imposition serves to further entrench the position of English. The view of "English" that has been institutionalized is of a testable entity that is easy to quantify (e.g. lectures are supposedly either in English or they are not). As capitalist enterprises, universities, just as individuals, are driven by the competition for profit. As regards mass-mediated university rankings, English MoI is a highly cost-effective way to improve institutional standing because "English" is again used as a quantifiable index of "globalization." Finally, academic competition interlocks with media competition in university rankings where one market drives the other, with both subject to the capitalist imperative to make a profit. These interlocking connections between capitalist and state-regulated competition on the terrain of English are naturalized through the ideologies of neoliberal free-market fundamentalism. As Bourdieu \& Passeron (1990:185) pointed out many years ago: "it is only by sheer force of ideology that one can present the 'needs of the economy' or of Society as the rational, reasonable basis for a consensus on the hierarchy of the functions incumbent upon the educational system."

In order for these interlocking impositions to make sense and for economic and academic restructuring to be promoted as a success, their costs need to be concealed as costs. With Bourdieu (Sapiro 2010), we believe that it is one of the most effective resistance strategies to neoliberalism to expose its costs. While the benefits of English proficiency to some individuals in South Korea are obviously substantial, the costs of English to the common good are potentially much larger. No one has, to the best of our knowledge, calculated the financial cost of the spread of English in South Korea. However, given that most observers agree that Koreans buy into English at comparatively high levels, it is safe to assume that they would be proportionally higher than the Euro ten billion per annum calculated by François Grin as the net worth of language subsidies that EU countries pay to the United Kingdom and Ireland in the form of privileged market effects, language learning savings effects, and alternative human capital investment effects (quoted in Phillipson 2008:28). The long-term costs incurred by the excessive focus on short-term competitive advantages also remain to be calculated.

In addition to the financial burden posed by English, the human cost of the alliance between competition and English is extremely high. By definition, only very few institutions and individuals can succeed in this race where the winner takes it 
all. Those that are found to be underperforming at each stage of South Korea's shiheom jiok 'exam hell' are condemned to the social suffering of "losers," with some of them feeling that the only "choice" they have left is that of taking their own lives.

Finally, the cost of the global spread of English through neoliberal structures of competition must also be counted in the suppression of free speech. Indeed, it is the central argument of Klein's (2007) trenchant critique of neoliberalism that the imposition of the "free market" has been achieved, in nation after nation, through the suppression of free speech, in some cases through severe human rights abuses. Some of the suppression of free speech we have documented in this article is stark and heavy-handed, and easily recognizable as such (e.g. editing wars on Wikipedia; designating parents as guarantors for their children's conformity). However, maybe even more insidious is the fact that the tools to enforce compliance in the academy that restructuring has created have served as a means of dismantling the critical modes of knowledge production (Chen 2009). This cost, too, is obscured by English as the perpetual need to perform academically-as a student, a teacher, or a researcher-in a language that comes naturally to very few in South Korea trains the critical faculties on the medium rather than the message.

\section{N O T E S}

*We gratefully acknowledge discussions on www.languageonthemove.org, particularly comments at $\mathrm{http} / / / \mathrm{www}$.languageonthemove.com/language-globalization/does-internationalization-change-re-

search-content, http://www.languageonthemove.com/multilingual-academics/academic-capitalismand-the-spread-of-english, and http://www.languageonthemove.com/multilingual-academics/the-colonial-cringe-in-academia, as well as discussions with audiences at Ludwig-Maximilian-University Munich, Germany, and at the University of Isfahan, Iran, where the first-named author presented earlier versions of this article.

${ }^{1}$ Cited in Sapiro (2010:247).

"Economic restructuring" is more commonly referred to as "neoliberal reforms" or "free market reforms." We follow Sapiro (2010) in avoiding the term "reform" for the processes we describe here because the term "reform" suggests a progressive process and thereby dissimulates the fact that economic restructuring is in fact a conservative restitution winding back the reforms of capitalism resulting from the struggles of the labor movement.

${ }^{3}$ Here and elsewhere we follow the Revised Romanization (or New Government Romanization) system published by the National Institute for the Korean Language (see http://www.korean.go.kr/ eng/roman/roman.jsp) except for proper nouns where another Romanization has become customary.

${ }^{4} \mathrm{An}$ anonymous reviewer pointed out that this must be understood within the Korean political climate and bureaucracy, in relation to the tension between the conservative status quo and progressive movements, and not just about competition itself.

${ }^{5}$ See also the KAIST mission statement at http://www.kaist.edu/edu.html (accessed September 2011).

${ }^{6}$ Curriculum Vitae of Dr. SUH, Nam Pyo. Online: http://www.kaist.edu/edu.html (accessed September 2011).

${ }^{7}$ http://m.kaist.edu/sub03/sub03_02_tab2.html (accessed September 2011).

${ }^{8} \mathrm{http}: / / j k 1123 . \mathrm{com} / \mathrm{sub} 3 \_1 . \mathrm{htm} ? \mathrm{table}=\mathrm{my} 1 \& \mathrm{st}=\mathrm{view} \& \mathrm{page}=1 \& \mathrm{id}=111 \&$ limit $=\&$ keykind $=\& \mathrm{key}-$ word=\&bo_class; entry dated 2011-04-10 (last accessed September 2011). 


\section{NEOLIBERALISM AS LANGUAGE POLICY}

\section{R E F E R E N C E S}

Abelmann, Nancy; So Jin Park; \& Hyunhee Kim (2009). College rank and neo-liberal subjectivity in South Korea: The burden of self-development. Inter-Asia Cultural Studies 10(2):229-47.

AFP (2011). Teen suicides on the rise due to exam pressure. Emirates 24/7. Online: http://www.emirates247.com/news/world/teen-suicides-on-the-rise-due-to-exam-pressure-2011-06-10-1.402044; accessed September 2011.

Ahn, Seokbae; Inyeol Lee; Jihye Lee; Soohyun Choi; \& Hyunseok Oh (2009). 2009 아시아 대학평가] “연구수준이 대학수준” [Asian university rankings 2009: Research capability equates institutional quality]. Chosun Ilbo. Online: http://issue.chosun.com/site/data/html_dir/2009/05/12/ 2009051200442.html; accessed September 2011.

Anonymous (2008). 카이스트 서남표 총장 및 학교의 횡포를 고발합니다 [KAIST President NamPyo Suh and schools stand accused of tyranny]. Leaflette. Online: http://blog.leaflette.com/558; accessed September 2011.

Barbara (2010). NSAA Test/“Ilje gosa" - what impact? what value? Online: http://www.freedteachers. org/forum/nsaa-test-ilje-gosa-what-impact-what-value.

Bourdieu, Pierre, \& Jean-Claude Passeron (1990). Reproduction in education, society and culture. 2nd edn. London: Sage.

Chae, Eunha (2011). "베르테르 효과” 앞세운 서남표 총장 지원군 <조선일보> [Chosun Ilbo a staunch ally of "Werther effect" president Nam-Pyo Suh]. Pressian. Online: http://www.pressian. com/article/article.asp?article_num=60110411170743\&section=03; accessed September 2011.

Chen, Kuan-Hsing (2009). Editorial introduction. Inter-Asia Cultural Studies 10(2):179-80.

Cho, Jinhyun 2012. Campus in English or campus in shock? Korean students hit hard by Englishmedium lectures. English Today, 28(2):18-25.

Choe, Sang-Hun (2008). South Korean science prepares to take on the world. New York Times. Online: http:// www.nytimes.com/2008/01/18/world/asia/18iht-school.1.9319863.html; accessed September 2011.

Choi, Jangseop (2010). The concept and production of "Suicide Republic." Open out put: The platform for young talents in design and architecture. Online: http://www.open-output.org/filebin/images/ 3784/025bbfecfc69de959b5df49ef8116ae0.pdf; accessed September 2011.

Choi, Po King (2010). "Weep for Chinese university": A case study of English hegemony and academic capitalism in higher education in Hong Kong. Journal of Education Policy 25(2):233-52.

Duménil, Gérard, \& Dominique Lévy (2009). Thirty years of neoliberalism under US hegemony. Online: http://www.jourdan.ens.fr/levy/dle2009b.htm; accessed January 2012.

Ehrenberg, Ronald G. (2003). Method or madness? Inside the USNWR college rankings. Cornell University ILR School Working Papers. Online: http://digitalcommons.ilr.cornell.edu/cgi/viewcontent. cgi?article $=1043 \&$ context=workingpapers \&sei-redir $=1 \#$ search $=\% 22$ ehrenberg $\% 20$ university $\%$ 20rankings\%20cornell\%22.

Gyeonggi English Village. (2006). Creating global Koreans. Online: http://www.english-village.or.kr/ exclude/userIndex/engIndex.do; accessed September 2011.

Han, Yongsoo; Hayoung Shin; Sungmin Jung; Hyunhui Min; Hyung Kim; \& Junghyuk Lee (2009). 대학평가 재탕기사 게재, '서열화' 우려 [Recycling of university ranking results risks causing numerical ordering of institutions]. Daily UNN. Online: http://www.unn.net/News/detail.asp? nsCode $=54846$; accessed September 2009.

Heller, Monica (2010). The commodification of language. Annual Review of Anthropology 39:101-14. , \& Alexandre Duchêne. (2012). Pride and profit: Changing discourses of language, capital and nation-state. In Alexandre Duchêne \& Monica Heller (eds.), Language in late capitalism: Pride and profit, 1-21. New York: Routledge.

James, R., \& Ka-Ho Mok. (2005). Globalization and higher education in East Asia. Singapore: Marshall Cavendish Academic.

Jang, Minseok (2009). 캠퍼스는 영어마을, 아 유 오케이? [English-obsessed campus, are you ok?]. Sixty Minutes (KBS). Online: http://www.kbs.co.kr/1tv/sisa/chu60/vod/1611698_879.html; accessed September 2011. 


\section{INGRID PILLER AND JINHYUN CHO}

(2010). 일간지평가는 대학 발전을 위한 ‘진단’ [Media-led university rankings are prescriptions for institutional development]. Korea University Newspaper. Online: http://www.kukey.com/ news/articleView.html?idxno=15772; accessed September 2011.

Jeon, Jin-Sik (2011). Uproar over selective Wikipedia editing by KAIST administration. The Hankyoreh. Online: http://english.hani.co.kr/arti/english_edition/e_national/489260.html; accessed September 2011.

Ji, Myunghoon; Kiwoo Jang; \& Sungkyu Kim (2011). KAIST 학생 또 자살]석달새 4명 자살... 충격의 KAIST, 학생측 요구 즉각 수용 [After four student suicides within three months KAIST immediately accepted demands from students]. Donga Ilbo. Online: http://m.donga.com/3/03/ 20110408/36249508/2; August 2011.

Jung, Wonsik (2011). [사회]경쟁의 정글로 몰아넣는 ‘대학평가' [University ranking stoking cutthroat competition in Korean society]. Weekly Kyunghyang. Online: http://weekly.khan.co.kr/ khnm.html?mode=view\&code=115\&artid=201104271925341; accessed September 2011 .

Kang, Myungkoo (2009). "State-guided" university reform and colonial conditions of knowledge production. Inter-Asia Cultural Studies 10(2):191-205.

Kauppi, Niilo, \& Tero Erkkilä (2011). The struggle over global higher education: Actors, institutions, and practices. International Political Sociology 5(3):314-26.

Kim, Hyejin (2008). Korea: Teachers who have been fired. Online: http://globalvoicesonline.org/2008/ 12/23/korea-teachers-who-have-been-fired/.

Kim, Manjung (2011). '카이스트' 무한경쟁.영어 몰입 교육.소통부재...고대, 중앙대가 시발 [KAIST's cutthroat competition, English immersion classes, absence of interaction begun by Korea University and Choongang University]. Voice of the People. Online: http://www.vop.co.kr/ A00000382993.html; accessed September 2011.

Kim, Minjee (2011). 서남표 개혁안이 카이스트 연쇄 자살 원흉”: 여야, KAIST사태 질타 한목소리...서남표 총장 “사퇴 고려 안해 [Suh's reforms responsible for consecutive suicides at KAIST]. Sisa Seoul. Online: http://www.sisaseoul.com/news/articleView.html?idxno=39931; accessed September 2011.

Klein, Naomi (2007). The shock doctrine: The rise of disaster capitalism. Camberwell: Penguin.

Ko, Dongouk (2010). 카이스트의 비극, 조선일보에 책임을 묻는다 [Chosun Ilbo held responsible for KAIST tragedy]. Media Today. Online: http://www.mediatoday.co.kr/news/articleView.html? idxno=94769; accessed September 2011.

Kolo, Vincent (2011). China's "rotten apple:" Worldwide protests against IT giant's labour abuses. Socialist Worker. Online: http://www.socialistworld.net/print/5056; accessed August 2011.

Korean universities: A brief introduction (2011). Hallyu Online. Online: http://www.hallyuonline.com/ en/lifestyle/living/1637-korean-universities-a-brief-introduction; accessed September 2011.

Lee, Euiheon (2009). '잘 팔리는 상품' 너도나도 랭킹장사 “학교 줄세우기, 교육 도움 안 된다” [Lucrative ranking business - numerical ordering of schools obstructs education]. Kyosoo Shinmun. Online: http://www.kyosu.net/news/quickViewArticleView.html?idxno=18535; accessed September 2011.

Lee, Jihye (2011). [단독] '잇단 자살' 카이스트에 눈가리고 입막는 '서약서' 있다 [KAIST has a statement to gag students]. Nocut News. Online: http://www.nocutnews.co.kr/show.asp? idx=1771909; accessed September 2011.

Lim, Hyun-Chin, \& Jin-Ho Jang (2006). Neo-liberalism in post-crisis South Korea: Social conditions and outcomes. Journal of Contemporary Asia 36(4):442-63.

McDonald, Mark (2011). Elite South Korean University rattled by suicides. New York Times. Online: http://www.nytimes.com/2011/05/23/world/asia/23southkorea.html?_r=2\&pagewanted=all; accessed August 2011.

Morgan, John (2010). Appetite for education. Times Higher Education. Online: http://www.timeshighereducation.co.uk/story.asp?storycode=414509; accessed September 2011.

Normile, Dennis (2007). MIT engineer shakes Korean academia to its core. Science 318(5855):1371.

Oh, Hyunseok (2009). 졸업 생 평판도 조사는? [How are graduates assessed?]. Chosun Ilbo. Online: http:// issue.chosun.com/site/data/html_dir/2009/06/23/2009062300451.html; accessed September 2011. 


\section{NEOLIBERALISM AS LANGUAGE POLICY}

Park, Joseph Sung-Yul (2009). The local construction of a global language: Ideologies of English in South Korea. Berlin: Mouton de Gruyter.

(2010). Naturalization of competence and the neoliberal subject: Success stories of English language learning in the Korean conservative press. Journal of Linguistic Anthropology 20(1):22-38.

- (2011). The promise of English: Linguistic capital and the neoliberal worker in the South Korean job market. International Journal of Bilingual Education and Bilingualism 14(4):443-55.

$\longrightarrow$, \& Sohee Bae (2009). Language ideologies in educational migration: Korean jogi yuhak families in Singapore. Linguistics and Education 20(4):366-77.

Park, So Jin, \& Nancy Abelmann (2004). Class and cosmopolitan striving: Mothers' management of English education in South Korea. Anthropological Quarterly 77(4):645-72.

Phillipson, Robert (2008). The linguistic imperialism of neoliberal empire. Critical Inquiry in Language Studies 5(1): 1-43.

Piller, Ingrid (2011). Intercultural communication: A critical introduction. Edinburgh: Edinburgh University Press.

— - Kimie Takahashi; \& Yukinori Watanabe (2010). The dark side of TESOL: The hidden costs of the consumption of English. Cross-Cultural Studies 20:183-201.

Recovery from the Asian crisis and the role of the IMF (2000). Online: http://www.imf.org/external/np/ exr/ib/2000/062300.htm\#I; accessed August 2011.

Reinert, Erik S. (2008). How rich countries got rich ... and why poor countries stay poor. London: Constable.

Sa, Eun Suk (2009). The press and democracy in South Korea: A survey of print journalists' opinions. Asian Social Science 5(3)3-24.

Sapiro, Gisèle (ed.) (2010). Sociology is a martial art: Political writing by Pierre Bourdieu. New York: The New Press.

Shin, Kwang-Yeong, \& Byoung-Hoon Lee (2010). Social class and educational inequality in South Korea. In Paul Attewell \& Katherine S. Newman (eds.), Growing gaps: Educational inequality around the world, 105-23. New York: Oxford University Press.

Slaughter, Sheila, \& Gary Rhoades (2004). Academic capitalism and the new economy: Markets, state, and higher education. Baltimore, MD: Johns Hopkins University Press.

Song, Inho (2011). 대한민국은 자살공화국? [Is the Republic of Korea suicide republic?]. SBS. Online: http://news.sbs.co.kr/section_news/news_read.jsp?news_id=N1000982599; accessed September 2011.

Song, Jesook (2009a). Between flexible life and flexible labor: The inadvertent convergence of socialism and neoliberalism in South Korea. Critique of Anthropology 29(2):139-59.

- (2009b). South Koreans in the debt crisis: The creation of a neoliberal welfare society. Durham, NC: Duke University Press.

Song, Juyoung (2010). Language ideology and identity in transnational space: Globalization, migration, and bilingualism among Korean families in the USA. International Journal of Bilingual Education and Bilingualism 13(1):23-42.

Asian Scientist Newsroom (2011). String of suicides at KAIST linked to tough policies. Asian Scientist. Online: http://www.asianscientist.com/education/string-suicides-kaist-linked-tough-policies/; accessed August 2011.

Stiglitz, Joseph (2002). Globalization and its discontents. London: Penguin.

Stuckler, David; Lawrence King; \& Martin Mckee (2009). Mass privatisation and the post-communist mortality crisis: A cross national analysis. The Lancet 373:399-407.

Stone, Richard (2006). Armed with cash, institute chief launches an education "Blitzkrieg." Science 311:321.

Teen suicide (2010). Korea Times. Online: http://www.koreatimes.co.kr/www/news/opinon/2010/08/ 202_71810.html; accessed September 2011.

University Ranking Team (2010). 2010 중앙일보 대학평가 지표 [Joongang Ilbo's university ranking criteria 2010]. Joinsmsn. Online: http://article.joinsmsn.com/news/article/article.asp?ctg=12\&Tota1_ID=4475958; accessed September 2011. 
Wohn, D. Yvette (2006). Premier science university ousts unpopular president. Science 312(5770):3233.

World Health Organization (2011). Suicide rates per 100,000 by country, year and sex. Online: http:// www.who.int/mental_health/prevention/suicide_rates/en/; accessed September 2011.

Yongjadeul (2008). 카이스트 '서남표식 교육혁신', 그 실상은 [The realities of Suh's institutional reforms]. Pressian. Online: http://www.pressian.com/article/article.asp?article_num=6008042216310 6\&Section=; accessed September 2011.

Yoo, Byungryul; Isak Kim; \& Hyekyung Kim (2011). 영어교육 강화? 사교육 심화 [Strengthening English education? Private tutoring on the increase]. Hankook Ilbo. Online: http://news.hankooki. com/lpage/society/200903/h2009031002351922020.htm; accessed September 2011.

Zamiska, Nicholas (2007). As it struggles to change, school mirrors Korea's woes: Kaist sought overhaul, hired a Nobel laureate; Radical ideas got an 'F.' Wall Street Journal. Online: http://large.stanford.edu/history/kaist/references/wsj/; accessed September 2011.

(Received 29 September 2011; revision received 27 March 2012; accepted 6 April 2012; final revision received 8 July 2012) 